\title{
Pengaruh Faktor Internal dan Faktor Eksternal terhadap Perataan Laba Bank Umum Syariah Indonesia Periode 2014-2018
}

The influence of internal factors and external factors on income smoothing of Islamic banks in Indonesia for the period 2014-2018

\section{Setiawati Indah Gempita}

Program Studi D4 Keuangan Syariah, Politeknik Negeri Bandung

E-mail: setiawati.indah.ksy16@polban.ac.id

\section{Leni Nur Pratiwi}

Jurusan Akuntansi, Politeknik Negeri Bandung

E-mail: leni.pratiwi@polban.ac.id

\section{Rani Putri Kusuma Dewi}

Program Studi Magister Ekonomi Islam, UIN Sunan Gunung Djati Bandung E-mail: putrikusumadewirani@gmail.com

\begin{abstract}
This study aims to see the effect of Total Financing (TF), Non Performing Financing (NPF), Earnings Before Taxes and Provision (EBTP), Good Corporate Governance (GCG) proxied by the Audit Committee, Capital Adequacy Ratio (CAR), BI rate. and Inflation on Income Smoothing at Islamic Commercial Banks (BUS) for the period 2014-2018. This research is a quantitative study, the selection was by purposive sampling method. The data used are secondary data. The data analysis method usespanel data regression analysis using the Eviews 10 program tool. The data population in this study were 12 Islamic commercial banks in Indonesia which will be sampled in the study. The results of this study indicate that simultaneously internal and external factors have a significant effect on income smoothing. Partially the NPF, EBTP, GCG, CAR variables have a significant effect on income smoothing, while TF, BI rate and the inflation rate do not have a significant effect on income smoothing.
\end{abstract}

Keywords: sharia banking, Islamic accounting, earnings management, income smoothing

\section{Pendahuluan}

Informasi laba adalah salah satu komponen laporan keuangan yang memiliki tujuan untuk membantu mengestimasikan kemampuan laba yang representatif dalam jangka panjang, menilai kinerja dari manajemen, dan menaksir risiko investasi (Irawati dan Maya, 2007). Laba menjadi informasi penting bagi para calon investor untuk melakukan pengambilan keputusan mengenai investasi yang akan dilakukannya.

Salah satu tindakan yang dilakukan oleh manajemen agar kinerjanya dapat dinilai baik dengan melakukan earnings management (Prakarsa dan Setiawan, 2018). Salah satu bentuk dari earnings management adalah praktik perataan laba. Manajemen laba yang dilakukan oleh manajer bertujuan untuk mengurangi fluktuasi laba yang dilakukan sehingga laba terlihat stabil dari periode ke periode. Manajemen laba dapat diklasifikasikan kedalam dua kategori yaitu Accruals Management dan Real Activities Manipulation (Zang, 2012)

Penyisihan Penghapusan Aktiva Produktif (PPAP) merupakan cadangan yang harus dibentuk 
sebesar persentase tertentu dari jumlah kredit berdasarkan penggolongan kualitas aktiva produktif sebagaimana ditetapkan dalam Peraturan Bank Indonesia (Rinanti, 2012). Perbankan yang ada di Indonesia wajib membentuk PPAP berupa cadangan khusus dan cadangan umum yang berguna untuk menutupi risiko kemungkinan yang akan terjadi dimasa yang akan datang. Aktivitas perataan laba pada Bank Umum Syariah masih sedikit meskipun bank syariah memiliki karakteristik yang unik. Pertama bank syariah diatur oleh prinsip syariah yang menggunakan pembagian risiko, kedua adanya regulasi akuntansi syariah tidak membatasi adanya penggunaan dynamic provision (kebijakan yang nilainya berubah-ubah). Penggunaan PPAP untuk perataan laba didasarkan atas fakta bahwa perubahan terhadap PPAP tidak menimbulkan dampak terhadap arus kas sehingga arus kas tidak terpengaruh, serta PPAP merupakan pretax item, sehingga jika nilai PPAP mengalami perubahan, akan berpengaruh pada nilai laba bersih yang dihasilkan atau jumlah pajak yang akan dibayarkan.

Dalam ekonomi konvensional, tidak ada aturan baku yang menyatakan larangan perusahaan untuk melakukan perataan laba. Sebab usaha perataan laba merupakan bagian dari manajemen laba yang merupakan tindakan para manajer baik itu secara agensi maupun personal dalam mencari keuntungan perusahaan. Sedangkan ekonomi islam menggunakan fiqh muamalab Islam, dalam kaidah fiqh yang digunakan untuk mengidentifikasi transaksi-transaksi ekonomi juga menggunakan kaidah fiqh muamalah. Hukum asal dalam urusan muamalah adalah boleh, kecuali ada dalil yang mengharamkannya. Fenomena earnings management yang didalamnya terkandung perataan laba merupakan tindakan yang akan membangun citra (image) dan kemampuan dalam usaha pengembangan perusahaan.

Adanya praktik perataan laba dapat dilakukan dengan menggunakan perhitungan Indeks Eckel, yaitu dengan perbandingan koefisien variasi dari perubahan laba bersih (net income) dengan koefisien variasi dari perubahan total pendapatan bersih. Untuk menguatkan fenomena yang ada penulis melakukan perhitungan indeks eckel dengan sampel 12 Bank Umum Syariah di Indonesia dengan melakukan purposive sampling. Angka indeks yang kurang dari 1 diklasifikasikan sebagai perata laba), sedangkan lebih besar dari 1 diklasifikasikan bukan perata laba (Kustono, 2010).

Tabel. 1 Nilai Indeks Eckel

\begin{tabular}{|c|c|c|c|}
\hline No & Nama Bank & $\begin{array}{l}\text { Indeks Eckel } \\
(\mathrm{CV} \Delta \mathrm{I} / \mathrm{CV} \Delta \mathrm{S})\end{array}$ & Keterangan \\
\hline 1. & Bank Bukopin Syariah & 8,17 & Bukan Pelaku Perataan Laba \\
\hline 2. & BNI Syariah & 0,74 & Pelaku Perataan Laba \\
\hline 3. & BRI Syariah & 0,98 & Pelaku Perataan Laba \\
\hline 4. & BCA Syariah & 0,23 & Pelaku Perataan Laba \\
\hline 5. & Bank Panin Syariah & 38,19 & Bukan Pelaku Perataan Laba \\
\hline 6. & Bank Muamalat & 0,82 & Pelaku Perataan Laba \\
\hline 7. & Bank Mega Syariah & 0,19 & Pelaku Perataan Laba \\
\hline 8. & Bank Victoria Syariah & 2,40 & Bukan Pelaku Perataan Laba \\
\hline 9. & Bank Maybank Syariah & 28,11 & Bukan Pelaku Perataan Laba \\
\hline 10. & Bank Syariah Mandiri & 0,01 & Pelaku Perataan Laba \\
\hline 11. & BJB Syariah & 5,94 & Bukan Pelaku Perataan Laba \\
\hline 12. & BTPN Syariah & 3,35 & Bukan Pelaku Perataan Laba \\
\hline \multicolumn{3}{|c|}{ Jumlah Bank pelaku perataan laba $\%$} & 50,0 \\
\hline
\end{tabular}


Dengan adanya fakta mengenai aktivitas perataan laba adalah dapat dipengaruhi oleh faktor internal dan faktor eksternal. Faktor internal bank diantaranya rasio keuangan dari bank itu sendiri sedangkan faktor eksternal yaitu kondisi makro ekonomi (KME). Faktor internal yang pertama mempengaruhi perataan laba adalah Good Corporate Governance. Dengan keputusan ketua BAPEPAM No.Kep-41/PM/2003 yang menyebutkan bahwa komite audit bertugas untuk memberikan pendapat kepada dewan komisaris terhadap laporan keuangan (Gradiyanto, 2012). Faktor internal yang kedua dan ketiga yang mempengaruhi praktik perataan laba adalah jumlah pembiayaan dan risiko pembiayaan yang termasuk dalam komponen non-discretionary dari objek perataan laba. Faktor internal keempat adalah EBTP ketika bank syariah memiliki tingkat profitabilitas yang tinggi, maka kecenderungan manajer untuk meningkatkan cadangan kerugiannya. Faktor internal yang kelima adalah CAR semakin tinggi rasio CAR maka akan meningkatkan cadangan PPAP pada suatu bank. Selain faktor internal adapun faktor Eksternal yang akan mempengaruhi praktik perataan laba pada BUS yaitu BI rate dan Inflasi.

\section{Kajian Pustaka}

\subsection{Akuntansi Perbankan Syariah}

Menurut Ikatan Akuntan Indonesia (IAI) dalam Kerangka Dasar Penyusunan dan Penyajian laporan Keuangan Syariah (KDPPLKS), Standar Akuntansi Keuangan (2009), aktivitas perbankan syariah berlandaskan pada paradigma dasar bahwa alam semesta diciptakan oleh Tuhan sebagai amanah (kepercayaan) dan sarana kebahagiaan hidup bagi umat manusia untuk mencapai kesejahteraan yang hakiki secara material dan spiritual (al-falah). Untuk itu transaksi syariah berasaskan prinsip: persaudaraan (ukhuwab), keadilan ('adalab), kemaslahatan (maslabab), keseimbangan (tawazun), dan universalisme (syumuliyab). Kegiatan operasional bank syariah harus menjalankan fungsinya sesuai dengan prinsip syariah.

\subsection{Teori Keagenan (Agency Theory)}

Teori keagenan membahas tentang adanya hubungan keagenan antara principal dan agent (Pudyastuti, 2009). Adanya masalah keagenan (agency problem) antara principal dengan agent. Permasalahan manajemen laba merupakan masalah keagenan yang sering dipicu oleh adanya pemisahan peran atau perbedaan kepentingan antara pemilik (pemegang saham) dengan pengelola perusahaan (manajemen). Menurut Hendriksen dan Breda (2002) mengungkapkan bahwa timbulnya permasalahan antara agent dan principal adalah ketika manajemen bersikap tidak memperhitungkan risiko, sedangkan pemilik menghindari risiko. Konflik kepentingan antara principal dan agen tersebut dapat menimbulkan adanya asymmetric (kesenjangan informasi). Asimetri informasi antara agen dan principalmemberikan kesempatan kepada manajer (agen) untuk melakukan manajemen laba (earnings management).

\subsection{Manajemen laba}

Manajemen laba didefinisikan sebagai upaya manajer perusahaan untuk mempengaruhi informasi-informasi dalam laporan keuangan dengan tujuan untuk mengelabui stakeholderyang ingin mengetahui kinerja dan kondisi perusahaan. Dapat disimpulkan bahwa manajemen laba adalah usaha dari pihak manajemen yang dilakukan secara sengaja dalam memanipulasi laporan keuangan. Menurut Subramanyam dan John (2013) terdapat tiga motivasi yang dapat menjelaskan mengapa seorang manajer melakukan upaya manajerial diantaranya: Motivasi Regulasi, Motivasi Harga Saham dan Motivasi Perjanjian. Dengan adanya motivasi tersebut menjadikan alasan untuk seorang manajer melakukan tindakan manajemen laba yang dapat dilakukan dengan beberapa cara yaitu: Taking a Bath, Income Maximization (Memaksimalkan laba), Income Minimization (Menurunkan laba) dan Income Smoothing (Perataan laba). 


\subsection{Penyisihan Penghapusan Aktiva Produktif (PPAP)}

Menurut Peraturan Bank Indonesia Nomor 5/9/2003 tentang Penyisihan Penghapusan Aktiva Produktif (PPAP) bagi bank syariah, PPAP adalah cadangan yang harus dibentuk sebesar persentase tertentu dari jumlah kredit berdasarkan penggolongan kualitas aktiva produktif sebagaimana ditetapkan dalam Peraturan Bank Indonesia. Adapun tata-cara khusus pembentukan PPAP sebagaimana yang dijelaskan dalam PBI No.13/13/PBI/2011 tentang Penilaian Kualitas Aktiva bagi Bank Umum Syariah dan Unit Usaha Syariah. Ketetapan besaran PPAP sekurangkurangnya adalah 1\% dari seluruhaktiva produktif yag digolongkan lancar, tidak termasuk Sertifikat Wadiah Bank Indonesia dan Surat Utang Pemerintah. Sedangkan cadangan khusus PPAP ditetapkan sekurangkurangnya sebesar 5\% dari aktiva produktif yang digolongkan dalam perhatian khusus; $15 \%$ dari aktiva produktif yang digolongkan kurang lancar setelah dikurangi nilai agunan; $50 \%$ dari aktiva produktif yang digolongkan diragukan setelah dikurangi nilai agunan 100\% dari aktiva produktif yang digolongkan macet setelah dikurangi nilai agunan (Hijriyani dan Setiawan, 2017).

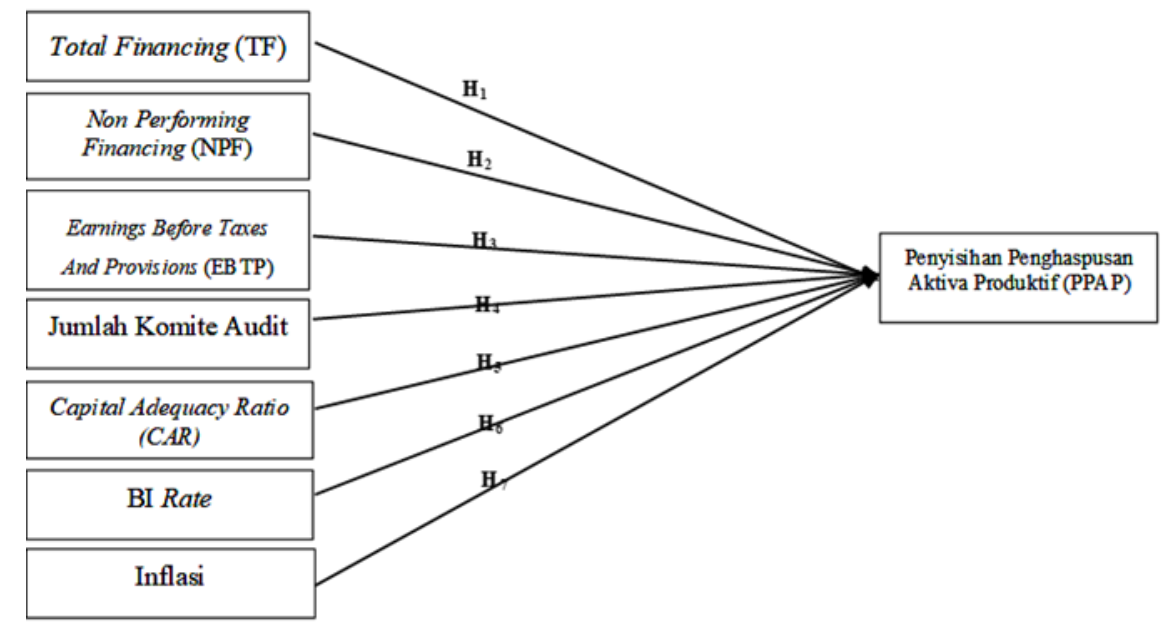

Gambar 1. Model Penelitian

\section{Metode Penelitian}

\subsection{Variabel Penelitian}

Variabel dependen yang digunakan dalam penelitian ini yaitu Perataan Laba yang diproksikan dengan PPAP. Nilai PPAP yang didapat langsung dari laporan keuangan publikasi bank Syariah dan dinormalisasi dengan total asset. Variablel independent yang digunakan dalam penelitian ini terdiri dari tujuh variable yaitu Total Financing (TF), Non Performing Financing (NPF), Earnings Before Taxes and Provisions, Jumlah Komite Audit, Capital Adequacy Ratio (CAR), BI rate, dan Inflasi.

\subsection{Penentuan Sampel}

Populasi yang digunakan dalam penelitian ini adalah perusahaan perbankan syariah berskala nasional di Indonesia dimana data yang digunakan dalam penelitian ini berasal dari Bank Umum Syariah (BUS) yang mempublikasikan laporan keuangan tahunan (annual report) untuk periode 2014 sampai dengan 2018, yang dapat langsung diakses melaui situs-situs perusahaan sampel.

\subsection{Metode Analisis}

Model analisis data yang digunakan pada penelitian ini adalah model regresi data panel. Berikut merupakan tahapan dalam melakukan analisis data kuantitatif data panel, dengan model sebagai berikut:

$$
\mathrm{PL}=a+\beta 1 \mathrm{TF}-\beta 2 \mathrm{NPF}+\beta 3 \mathrm{EBTP}+\beta 4 \mathrm{GCG}+\beta 5 \mathrm{CAR}+\beta 6 \mathrm{BI} \text { rate }+\beta 7 \mathrm{Inf}+\varepsilon
$$




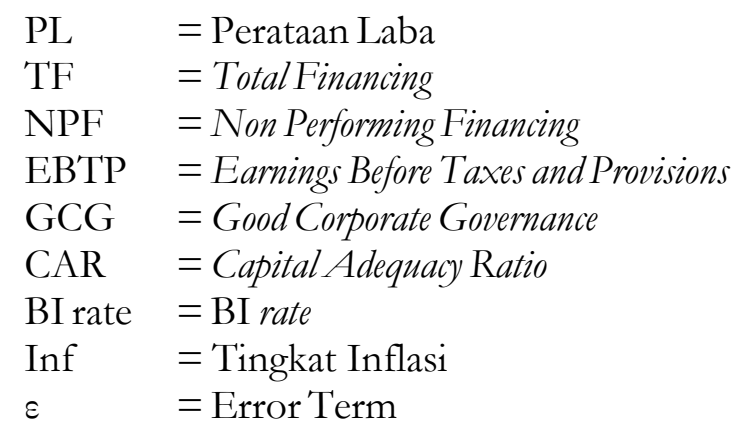

Berikut merupakan tahapan dalam melakukan analisis data kuantitatif data panel:

1. Pemilihan Metode Estimasi Regresi Data Panel
a. Common Effect Model (CEM)
b. Fixed Effects Model (FEM)
c. Random Effects Model (REM)

2. Uji Kesesuaian Model
a. Uji Chow Test
b. Uji Hausman Test
c. Uji Lagrange Multiplier (LM)

3. Pengujian Asumsi Klasik
a. Uji Normalitas
b. Uji Autokorelasi
c. Uji Multikolinearitas

4. Pengujian hipotesis
a. Koefisien Determinasi $\left(\mathrm{R}^{2}\right)$
b. UjiF
c. Ujit

\section{Hasil dan Pembahasan}

\subsection{Statistik Deskriptif}

Sampel yang digunakan dalam penelitian ini adalah 12 Bank Umum Syariah (BUS) yang terdaftar pada OJK selama tahun 2014-2018 dengan menggunakan purposive sampling. Berikut hasil pengujian statistik deskriptif:

Tabel. 2 Hasil Statistik Deskriptif

\begin{tabular}{|c|c|c|c|c|c|c|c|c|}
\hline & PPAP & TF & NPF & EBTP & GCG & CAR & BI_RATE & INFLASI \\
\hline Mean & 11.61667 & 15.60178 & 2.850833 & 11.60667 & 3.333333 & 3.056000 & 6.144000 & 4.294000 \\
\hline Median & 12.00000 & 15.45350 & 3.055000 & 11.75000 & 3.000000 & 2.960000 & 6.000000 & 3.350000 \\
\hline Maximum & 14.00000 & 18.34900 & 6.730000 & 15.00000 & 6.000000 & 5.090000 & 7.540000 & 8.360000 \\
\hline Minimum & 8.000000 & 8.523000 & 0.000000 & 6.000000 & 2.000000 & 2.440000 & 4.560000 & 3.020000 \\
\hline Std. Dev. & 1.616563 & 1.600269 & 1.669616 & 1.844448 & 1.257744 & 0.480654 & 1.231941 & 2.060245 \\
\hline Observations & 60 & 60 & 60 & 60 & 60 & 60 & 60 & 60 \\
\hline
\end{tabular}

Sumber: Data Olaba Eviews 10 (2020)

\subsection{Hasil Pemilihan Model Data}

Metode atau model regresi data panel yang digunakan pada penelitian ini yaitu Common Effect Model(CEM). Hasil tersebut merujuk pada hasil pengujian yang telah dilakukan. Berikut merupakan 
hasil Uji Lagrange Multiplier dengan menggunakan metode pooled:

Tabel. 3 Uji Lagrange Multiplier

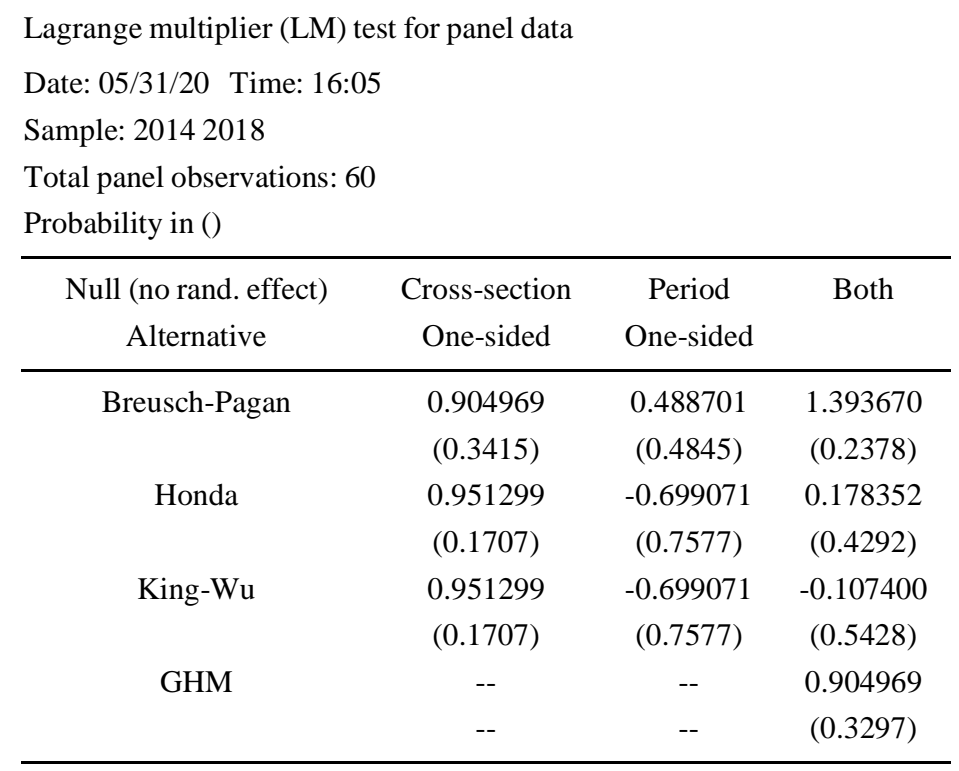

Berdasarkan tabel 3 di atas, hasil pengujian lagrange multiplier menunjukkan bahwa nilai cross section pada Breusch Pagan sebesar 0.3415 dimana nilai tersebut lebih besar dari taraf signifikansi yaitu sebesar 0,05 (5\%). Dari hasil tersebut maka dapat diambil kesimpulan model yang paling tepat digunakan pada penelitian ini adalah common effect model.

\subsection{Hasil Uji Asumsi Klasik}

\section{Uji Normalitas}

Berdasarkan pengujian yang dilakukan dengan melihat grafik Jarque-Bera diperoleh output sebagai berikut:

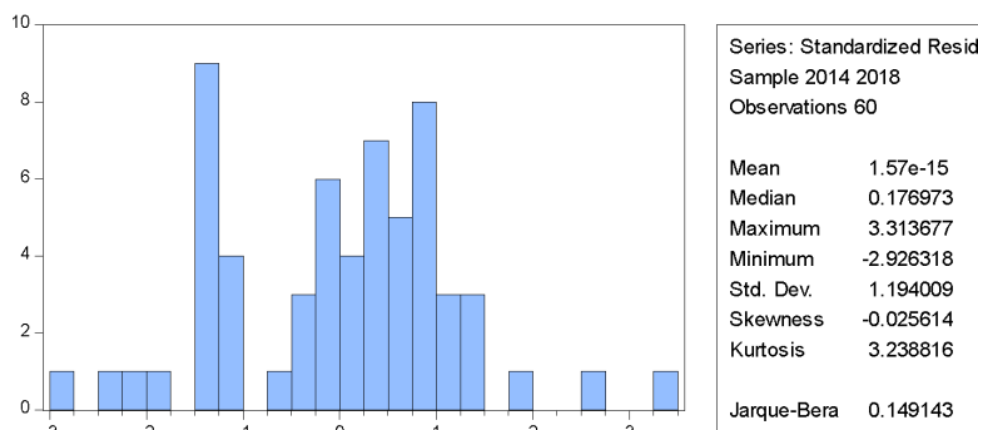

Gambar 1 Hasil Uji Normalitas J-B Test

Berdasarkan hasil pengujian pada menunjukkan bahwa data telah berdistribusi secara normal. Ditunjukkan dengan nilai probabilitas Jarque-Bera sebesar 0.9281 yang berada di atas 0.05. dapat diartikan data berasal dari populasi yang berdistribusi secara normal.

\section{Uji Autokorelasi}

Setelah dilakukan pengujian dengan metode Durbin-Watson (DW), maka didapatkan hasil yaitu sebagai berikut:

Tabel. 4 Hasil Uji Autokorelasi 


\begin{tabular}{llll}
\hline & & & \\
R-squared & 0.454456 & Mean dependent var & 11.61667 \\
Adjusted R-squared & 0.381018 & S.D. dependent var & 1.616563 \\
S.E. of regression & 1.271838 & Akaike info criterion & 3.442369 \\
Sum squared resid & 84.11372 & Schwarz criterion & 3.721615 \\
Log kelihood & -95.27107 & Hannan-Quinn criter. & 3.551597 \\
F-statistic & 6.188254 & Durbin-Watson stat & 1.686822 \\
Prob(F-statistic) & 0.000027 & & \\
\hline
\end{tabular}

Berdasarkan tabel 4.3 di atas menunjukkan bahwa hasil nilai dari Durbin $W$ atson statistik untuk Common Effect Modeladalah sebesar 1.6868 yang artinya tidak terjadi autokorelasi. Karena nilai 1.6868 berada di antara -2 dan +2 .

\section{Uji Multikolinearitas}

Berikut hasil dari uji multikolinearitas menggunakan Pearson Correlation:

Tabel. 5 Hasil Uji Multikolinearitas

\begin{tabular}{|c|c|c|c|c|c|c|c|c|}
\hline \multicolumn{9}{|c|}{$\begin{array}{l}\text { Covariance Analysis: Ordinary } \\
\text { Date: 06/04/20 Time: 10:12 } \\
\text { Sample: } 20142018 \\
\text { Included observations: } 60\end{array}$} \\
\hline \multicolumn{9}{|l|}{ Correlation } \\
\hline Probability & PPAP & $\mathrm{TF}$ & NPF & INFLASI & GCG & EBTP & CAR & BI_RATE \\
\hline PPAP & 1.000000 & & & & & & & \\
\hline TF & $\begin{array}{l}0.413348 \\
0.0010\end{array}$ & $\begin{array}{l}1.000000 \\
---\end{array}$ & & & & & & \\
\hline NPF & $\begin{array}{l}-0.032597 \\
0.8047\end{array}$ & $\begin{array}{l}0.119414 \\
0.3635\end{array}$ & $\begin{array}{l}1.000000 \\
----\end{array}$ & & & & & \\
\hline INFLASI & $\begin{array}{l}-0.191745 \\
0.1422\end{array}$ & $\begin{array}{l}0.065830 \\
0.6173\end{array}$ & $\begin{array}{l}0.081128 \\
0.5378\end{array}$ & $\begin{array}{l}1.000000 \\
---\end{array}$ & & & & \\
\hline GCG & $\begin{array}{l}0.480715 \\
0.0001\end{array}$ & $\begin{array}{l}0.337895 \\
0.0083\end{array}$ & $\begin{array}{l}0.034410 \\
0.7941\end{array}$ & $\begin{array}{l}-2.32 \mathrm{E}-17 \\
0.1000\end{array}$ & $\begin{array}{l}1.000000 \\
---\end{array}$ & & & \\
\hline ЕВTP & $\begin{array}{l}0.503377 \\
0.0000\end{array}$ & $\begin{array}{l}0.494656 \\
0.0001\end{array}$ & $\begin{array}{l}-0.267141 \\
0.0391\end{array}$ & $\begin{array}{l}-0.039561 \\
0.7641\end{array}$ & $\begin{array}{l}0.451277 \\
0.0003\end{array}$ & $\begin{array}{l}1.000000 \\
----\end{array}$ & & \\
\hline CAR & $\begin{array}{l}-0.262022 \\
0.0431\end{array}$ & $\begin{array}{l}-0.511378 \\
0.0000\end{array}$ & $\begin{array}{l}-0.344524 \\
0.0070\end{array}$ & $\begin{array}{l}-0.038530 \\
0.7701\end{array}$ & $\begin{array}{l}0.092801 \\
0.4807\end{array}$ & $\begin{array}{l}-0.021879 \\
0.8682\end{array}$ & $\begin{array}{l}1.000000 \\
---\end{array}$ & \\
\hline BI_RATE & $\begin{array}{l}-0.099643 \\
0.4488\end{array}$ & $\begin{array}{l}0.066274 \\
0.6149\end{array}$ & $\begin{array}{l}0.177893 \\
0.1739\end{array}$ & $\begin{array}{l}0.549669 \\
0.0000\end{array}$ & $\begin{array}{l}-1.94 \mathrm{E}-17 \\
0.1000\end{array}$ & $\begin{array}{l}-0.040620 \\
0.7580\end{array}$ & $\begin{array}{l}-0.083365 \\
0.5266\end{array}$ & $\begin{array}{l}1.000000 \\
---\end{array}$ \\
\hline
\end{tabular}

Berdasarkan tabel 5 di atas, menunjukkan bahwa nilai dari koefisien antar variabel lebih kecil dari 0,9. Hal ini sesuai dengan kriteria pengujian bahwa hasil dari uji multikolinearitas tidak ada nilai koefisien korelasi antar variabel yang lebih dari 0,9. Maka dapat disimpulkan bahwa data tidak memiliki masalah multikolinearitas.

\subsection{Hipotesis, Hasil dan Interpretasi}


Dependent Variable: PL

Method: Panel Least Squares

Date: 05/02/20 Time: 13:50

Sample: 20142018

Periods included: 5

Cross-sections included: 12

Total panel (balanced) observations:

60

\begin{tabular}{cclcc}
\hline Variable & Coefficient & Std. Error & t-Statistic & Prob. \\
& & & & \\
\hline & & & & \\
C & 11.20618 & 3.116476 & 3.595784 & 0.0007 \\
NPF & -0.014965 & 0.151834 & -0.098562 & 0.9219 \\
EBTP & -0.055859 & 0.115338 & -0.484311 & 0.0302 \\
GCG & 0.271953 & 0.120994 & 2.247653 & 0.0289 \\
CAR & 0.485629 & 0.157772 & 3.078044 & 0.0033 \\
BI_RATE & -1.092959 & 0.455293 & -2.400564 & 0.0200 \\
INFLASI & -0.000870 & 0.163074 & -0.005337 & 0.9958 \\
\hline R-squared & -0.145921 & 0.096520 & -1.511824 & 0.1366 \\
Adjusted R-squared & 0.454456 & Mean dependent var & 11.61667 \\
S.E. of regression & 1.271838 & S.D. dependent var & 1.616563 \\
Sum squared resid & 84.11372 & Skaike info criterion & 3.442369 \\
Log kelihood & -95.27107 & Hannarz criterion & 3.721615 \\
F-statistic & 6.188254 & Durbin-Watson criter. & 3.551597 \\
Prob(F-statistic) & 0.000027 & & 1.686822 \\
\hline
\end{tabular}

Sumber: Data Olaham Eviews 10 (2020)

Gambar 2 Hasil Uji CEM

a. Koefisien Determinasi $\left(\mathrm{R}^{2}\right)$

Berdasarkan Gambar 2 diatas, hasil nilai Adjusted R-squared yang diperoleh pada penelitian ini sebesar 0,3810 atau 38,10\%, sehingga dapat disimpulkan bahwa variabel independen yang terdiri dari TF, NPF,Inflasi, EBTP, GCG, CAR, BI rate hanya dapat menjelaskan variabel dependen yaitu perataan laba sebesar $38.10 \%$ dan sisanya sebesar $61.89 \%$ dapat dijelaskan oleh variabel lain yang tidak termasuk pada penelitian ini.

b. $\quad$ Uji F (Uji Simultan)

Hasil uji F dapat dilihat pada Gambar 2 berdasarkan hasil pengujian secara simultan ini dapat dilihat dari nilai Prob (F-statistic) yaitu sebesar 0.000027. Dari hasil tersebut maka dapat diambil kesimpulan bahwa $\mathrm{H}_{0}$ ditolak dan menerima $\mathrm{H}_{1}$ diterima, atau dalam kata lain berdasarkan pengujian hipotesis secara simultan (uji F), variabel independen dalam penelitian berpengaruh positif terhadap variabel dependen yaitu Perataan Laba.

c. Ujit (Uji Parsial) 
Hasil pengujian parsial dapat dilihat pada Gambar 2 berdasarkan hasil pengujian, untuk melihat pengaruh variabel bebas terhadap variabel terikat, maka dapat dilihat pada nilai probabilitas dan koefisien masing-masing variabel bebas diantaranya TF, NPF, EBTP, GCG, CAR, BI rate, dan Inflasi. Dapat diketahui bahwa nilai probabilitas dari TF $\left(\mathrm{X}_{1}\right)$ sebesar 0,9219 dan koefisien -0.0149. Nilai tersebut menunjukkan bahwa TF tidak berpengaruh terhadap perataan laba karena nilai probabilitasnya $>0,05$, maka secara parsial $\mathrm{H}_{1}$ ditolak. Nilai probabilitas dari $\mathrm{NPF}\left(\mathrm{X}_{2}\right)$ sebesar 0.0302 dan koefisien -0.0558. Nilai tersebut menunjukkan bahwa NPF berpengaruh negatif signifikan terhadap Perataan laba karena nilai probabilitasnya $<0,05$, maka secara parsial $\mathrm{H}_{2}$ diterima. Nilai probabilitas dari EBTP $\left(\mathrm{X}_{3}\right)$ sebesar 0.0289 dan koefisien 0.2719. Nilai tersebut menunjukkan bahwa EBTP berpengaruh positif signifikan terhadap Perataan laba karena nilai probabilitasnya $<0,05$, maka secara parsial $\mathrm{H}_{3}$ diterima. Nilai probabilitas dari GCG $\left(\mathrm{X}_{4}\right)$ sebesar 0.0033 dan koefisien 0.4856. Nilai tersebut menunjukkan bahwa GCG berpengaruh positif signifikan terhadap Perataan laba karena nilai probabilitasnya $<0,05$, maka secara parsial $\mathrm{H}_{4}$ diterima. Nilai probabilitas dari CAR $\left(\mathrm{X}_{5}\right)$ sebesar 0,0200 dan koefisien -1.0929. Nilai tersebut menunjukkan bahwa CAR berpengaruh negatif signifikan terhadap Perataan laba karena nilai probabilitasnya $<0,05$, maka secara parsial $\mathrm{H}_{5}$ ditolak. Nilai probabilitas dari $\mathrm{BI}$ rate $\left(\mathrm{X}_{6}\right)$ sebesar 0.9958 dan koefisien -0.00087. Nilai tersebut menunjukkan bahwa BI rate tidak berpengaruh terhadap Perataan laba, maka secara parsial $\mathrm{H}_{6}$ ditolak. Sedangkan untuk nilai probabilitas dari Inflasi $\left(\mathrm{X}_{7}\right)$ sebesar 0.1366 dan koefisien -0.1459. Nilai tersebut menunjukkan bahwa BI rate tidak berpengaruh terhadap Perataan laba, maka secara parsial $\mathrm{H}_{7}$ ditolak.

\subsection{Pembahasan Hasil Penelitian}

\subsubsection{Pengaruh Total Financing (TF) terhadap Perataan Laba}

Pembiayaan merupakan penyediaan uang atau tagihan yang nilainya diukur dengan uang berdasarkan kesepakatan antara bank dengan pihak peminjam. Adanya aktivitas pembiayaan tersebut maka bank akan menghitung PPAP sebesar persentase tertentu terhadap total kredit. Sebelumnya telah dijelaskan mengenai hasil uji parsial yang menunjukkan bahwa TF $\left(\mathrm{X}_{1}\right)$ tidak memiliki pengaruh signifikan dan menghasilkan hubungan negatif (berlawan arah) terhadap variabel dependen yaitu Perataan laba. Hal tersebut sejalan dengan hasil penelitian Adityawarman dan Iman (2015) dan Shofiani (2018) yang menyatakan bahwa Total Financing tidak memiliki pengaruh signifikan dan memiliki koefisien negatif terhadap perataan laba.

\subsubsection{Pengaruh Non Performing Financing(NPF) terhadap Perataan Laba}

Pembiayaan merupakan sumber pendapatan terbesar bagi BUS sekaligus merupakan sumber dari adanya risiko yang besar karena timbulnya pembiayaan yang bermasalah. Non Performing Financing (NPF) adalah resiko tidak terbayarnya pembiayaan yang disalurkan oleh bank (Anisa dan Tripuspitorini, 2019). Bila persentase NPF suatu bank tinggi maka kualitas dari pembiayaan yang telah disalurkan bank semakin buruk. Hal tersebut akan berdampak pada kerugian yang mempengaruhi pendapatan dan pencadangan pada Bank Syariah. Pada sub bab sebelumnya telah dijelaskan hasil uji parsial antara NPF terhadap PPAP yang menunjukkan bahwa NPF $\left(\mathrm{X}_{2}\right)$ memiliki pengaruh signifikan negatif (berlawan arah) terhadap variabel dependen yaitu Perataan laba. Penelitian ini mendukung hasil penelitian Utami (2017), Almunawwaroh dkk (2018) dan Maemunah dkk (2020) yang menyatakan bahwa risiko pembiayaan berpengaruh negatif terhadap praktik perataan laba.

\subsubsection{Pengaruh Earnings Before Taxes and Provisions (EBTP) Terhadap Perataan Laba}

EBTP merupakan laba operasi bersih sebelum pajak dan cadangan pada Bank Syariah. Semakin tinggi EBTP pada suatu bank maka kemampuan memperoleh laba akan semakin besar. Pada variabel EBTP $\left(\mathrm{X}_{3}\right)$ yang diproksikan sebagai profitabilitas berdasarkan hasil pengujian statistik memiliki pengaruh signifikan dan menghasilkan hubungan positif (berbanding lurus) terhadap 
variabel dependen yaitu perataan laba. Hasil penelitian ini sejalan dengan hasil penelitian Syahfandi (2012), Melinda dan Setiawan (2020) dan Ayu (2020) yang menyatakan bahwa EBTP yang berpengaruh positif terhadap perataan laba.

\subsubsection{Pengaruh Komite Audit Terhadap Perataan Laba}

Komite audit merupakan bagian dari penerapan GCG pada suatu perusahaan yang diketuai oleh dewan komisaris. Jika Bank Syariah memperhatikan pelaksanaan GCG dengan baik maka akan mempertahankan para pemegang saham, nas laba dan pemangku kepentingan lainnya untuk tetap berkontribusi pada perusahaan. Hasil uji parsial yang menunjukkan bahwa variabel independen GCG $\left(\mathrm{X}_{4}\right)$ yang diproksikan dengan Komite Audit memiliki pengaruh signifikan dan menghasilkan hubungan positif (berbanding lurus) terhadap variabel dependen yaitu Perataan laba. Hasil penelitian ini juga sejalan dengan penelitian dari Rosary dan Nuritomo (2017), Marpaung dan Latrini (2014) dan Soeharto (2018) yang menunjukkan bahwa komite audit berpengaruh positif dan menyatakan bahwa komite audit mempunyai peran penting dalam menurunkan atau menghambat terjadinya manajemen laba.

\subsubsection{Pengaruh Capital Adequacy Ratio(CAR) Terhadap Perataan Laba}

Rasio kecukupan modal memiliki tujuan untuk menampung risiko kerugian yang mungkin akan dihadapi oleh bank. Saat bank memiliki rasio CAR rendang maka kecenderungan manajemen untuk melakukan perataan laba akan semakin tinggi hal tersebut berguna untuk menghindari risiko pada bank. Hasil uji parsial pada pembahasan sebelumnya yang menunjukkan bahwa variabel independen CAR $\left(\mathrm{X}_{5}\right)$ dalam penelitian ini memiliki pengaruh signifikan dan menghasilkan hubungan negatif terhadap variabel dependen yaitu perataan laba. Penelitian ini sejalan dengan penelitian yang dilakukan oleh Kartika (2012) dan Ayu (2017) yang menunjukkan hasil pengaruh signifikan dengan koefisien negatif menyatakan bahwa ketentuan kewajiban pemenuhan batasan nilai minimum rasio CAR yang ditetapkan oleh Bank Indonesia tidak mempengaruhi akrual diskresioner.

\subsubsection{Pengaruh BI rate Terhadap Perataan Laba}

BI rate merupakan kebijakan dari Bank Sentral yang merupakan solusi dari inflasi temporal. BI Rate adalah suku bunga kebijakan yang mencerminkan sikap atas kebijakan moneter yang ditetapkan oleh bank Indonesia dan diumumkan kepada publik (Tripuspitorini dan Setiawan, 2020). Bank Syariah tidak mengacu pada tingkat suku bunga dan tidak mempengaruhi secara langsung. Hasil pengujian secara parsial menyatakan bahwa variabel independen $\mathrm{BI}$ rate $\left(\mathrm{X}_{6}\right)$ dalam penelitian tidak memiliki pengaruh signifikan terhadap variabel dependen yaitu Perataan laba. Hal tersebut didukung oleh Hidayanti (2014) dimana dalam penelitiannya menyatakan bahwa variabel BI rate tidak mempunyai pengaruh yang signifikan terhadap profitabilitas pada bank syariah.

\subsubsection{Pengaruh Inflasi Terhadap Perataan Laba}

Inflasi merupakan suatu keadaan yang menggambarkan perubahan tingkat harga dalam perekonomian. Menurut Tripuspitorini dan Setiawan (2020), menyatakan inflasi digunakan untuk mengartikan peningkatan persediaan uang yang kadangkala dilihat sebagai penyebab meningkatnya harga. Adanya inflasi akan melemahkan semangat menabung dan sikap terhadap menabung dari masyarakat. Meningkatkan kecenderungan untuk berbelanja terutama untuk kebutuhan non-primer dan barang-barang mewah. Hasil pengujian menunjukkan variabel independen ke- 7 yaitu Inflasi $\left(\mathrm{X}_{7}\right)$ dalam penelitian tidak memiliki pengaruh signifikan terhadap variabel dependen yaitu Perataan laba. Penelitian ini sejalan dengan penelitian Melinda dan Setiawan (2020) dan Rice (2014) yang menyatakan bahwa tingkat inflasi tidak memiliki pengaruh terhadap tindakan perataan laba.

\section{Penutup}

Total Pembiayaan (TF) tidak memiliki pengaruh signifikan dan menghasilkan hubungan negatif terhadap perataan laba. Risiko Pembiayaan (NPF) memiliki pengaruh negatif dan signifikan 
terhadap perataan laba yang berarti apabila nilai NPF tinggi maka kecenderungan bank untuk melakukan perataan laba akan semakin rendah. Sedangkan EBTP memiliki pengaruh positif dan signifikan terhadap perataan laba hal tersebut dikarenakan ketika bank syariah menerima pendapatan yang tinggi, maka bank cenderung akan meningkatkan jumlah cadangannya, demikian sebaliknya. Variabel keempat yaitu jumlah Komite Audit yang memiliki pengaruh positif dan signifikan terhadap perataan laba hal tersebut dikarenakan GCG mempengaruhi profitabilitas perusahaan, untuk Rasio Kecukupan Modal (CAR) memiliki pengaruh negatif dan signifikan terhadap perataan laba. Hasil dari faktor eksternal variabel keenam yaitu BI rate tidak memiliki pengaruh yang signifikan dan menghasilkan hubungan negatif terhadap perataan laba yang artinya meskipun kenaikan dari BI rate akan direspon baik dengan kenaikan bunga bank konvensional, kenaikan tingkat suku bunga tersebut tidak mempengaruhi bank syariah secara langsung. Sedangkan variabel ketujuh yaitu Inflasi tidak memiliki pengaruh yang signifikan dan menghasilkan hubungan negatif terhadap perataan laba.

\section{Daftar Pustaka}

Anisa S.L. dan Tripuspitorini. (2019). Analisis Pengarub Dana Pibak Ketiga, Non Performing Finance Murabahah, Dan Inflasi Terhadap Pembiayaan Murabahah Pada Bank Umum Syariah Di Indonesia. Jurnal Maps (Manajemen Perbankan Syariah).

Amy Y. Zang. (2012). Evidence On The Trade-Off Between Real Activities Manipulation And Accrual-Based Earnings Management. The Accounting Review: March 2012, Vol. 87, No. 2, Pp. 675-703.

Aprilliani, dan Aloysius. (2017). Pengarub Ukuran Dewan Komisaris dan Komite Audit Terbadap Manajemen Laba Pada Perusabaan Manufaktur Yang Terdaftar di Bursa Efek Indonesia Periode 2013-2015. Profita. Vol. 1, No.3 Desember 2017.

Atik, Djayanti. (2017). Pengarub Faktor Internal dan Persistensi Laba Pada Perataan Laba Bank. Jurnal Penelitian dan Karya Ilmiah Lemlit.

Ayunika, Ni Putu Nanda, dan Ketut Yadnyana. (2018). Pengarub Ukuran Perusabaan, Profitabilitasdan Financial Leverage Terhadap Praktik Perataan Laba Pada Perusahaan Manufaktur. E-Jurnal Akuntansi Universitas Udayana Vol.25.3.Desember (2018): 2402 - 2429.

Dunil, Z. (2005). Bank Auditing Risk-Based Audit Dalam Pemeriksaan Perkeditan Bank Umum. Jakarta: PT Indeks Kelompok Gramedia.

Ghozali, Imam. (2006). Aplikasi Analisis Multivariate Dengan Program SPSS (Edisi Ke 4). Semarang: Badan Penerbit Universitas Diponegoro.

Gradiyanto, Andrean. (2012.) Pengaruh Komite Audit Terhadap Praktik Manajemen Laba. Skripsi.

Handayani, Yustika. (2008). Analisis Perbedaan Manajemen Laba Sebelum dan Sesudab Penerapan Standar Akuntansi Kenangan (Konvergensi IFRS). Universitas Negeri Padang: (Skripsi Tidak Diterbitkan).

Harahap, S. Sofyan. (2010). Akuntansi Perbankan Syariah. Jakarta Barat: LPEE Usakti.

Herawaty, A, dan Welvin I Guna. (2010). Pengarub Mekanisme Good Corporate Governance, Independensi Auditor, Kualitas Audit dan Faktor Lainnya Terbadap Manajemen Laba. Jurnal Bisnis Dan Akuntansi.

Hijriyani. N.Z. dan Setiawan. (2017). Analisis Profitabilitas Perbankan Syariab Di Indonesia Sebagai Dampak Dari Efisiensi Operasional. Jurnal Kajian Akuntansi, Vol 1, (2), 2017, 194-209.

Iqbal, Zamir, dan Abbas Mirakhor. (2007). An Introduction To Islamic Finance Theory And Practice. Singapore: Wiley.

Irawati, Zulfa, dan Anugerah Maya. (2007). Analisis Perataan Laba (Income Smoothing) : Faktor Yang Mempengarubinya dan Pengarubnya Terbadap Return dan Risiko Sabam Pada Perusabaan Go Public Di 
Bursa Efek Jakarta. (Skripsi tidak dipublikasikan).

Jensen, Michael C. dan William H. Meckling. (1976). Theory Of The Firm: Managerial Behavior, Agency Costs And Ownership Structure. Journal Of Financial Economics, Volume 3, Issue 4 305-360.

Kustono, Alwan Sri. (2010). Indekes Eckel Sebagai Pengidentifikasi Perataan Penghasilan Yang Tidak Reliable. Jurnal Keuangan Dan Perbankan.

Mawardi, Wisnu. (2005). Analisis Faktor Yang Mempengarubi Kinerja Kenangan Bank Umum Di Indonesia (Studi Kasus Pada Bank Umum Dengan Total Aset Kurang Dari 1 Triliun). Jurnal Bisnis Dan Strategi Vol.14 No.1.

Melinda, Ros dan Setiawan, S. (2020). Faktor Internal dan Eksternal Perbankan Syariah yang Mempengarubi Tindakan Perataan Laba. Journal of Applied Islamic Economics and Finance 1 (1), 109-119.

Pasaribu, Heriyanto. (2018). Pengarub Penyisihan Penghapusan Aset Produktif (PPAP), Profitabilitas, Non Performing Financing (NPF), dan Financial Leverage Terbadap Praktik Perataan Laba Pada Bank Umum Syariah di Indonesia. (Skripsi tidak dipublikasikan). Universitas Sumatera Utara.

Prakarsa, R. A., \& Setiawan, S. (2018, October). Pengarub Profitabilitas, Leverage, Dan Ukuran Perusahaan Terhadap Praktik Perataan Laba (Studi Pada Perusahaan Keuangan Sub Sektor Perbankan Yang Terdaftar Di Bursa Efek Indonesia Periode 2015-2017). In Prosiding Industrial Research Workshop and National Seminar (Vol. 9, pp. 719-727).

Pudyastuti. (2009). Analisis Hubungan Mekanisme Corporate Governance, Ukuran Perusabaan dan Leverage Terbadap Manajemen Laba Pada Perusabaan Manufaktur Yang Terdaftar Di BEI. (Skripsi tidak dipublikasikan). Undip.

Rezhita, Novia, dan Nanang Sohnhadji. (2017). Pengarub Perkembangan Likuiditas, Inflasi, Car, Roa, dan LDR Terbadap Cadangan Kerugian Penurunan Nilai (CKPN) Pada Industri Perbankan Go Public di BEI. Artikel Ilmiah.

Rinanti, Risna. (2012). Analisis Faktor-Faktor Yang Mempengarubi PPAP (Studi Komparasi Bank Konvensional dan Bank Syariah di Indonesia). Jurnal Bisnis Strategi Vol 21 No 2.

Salim, Sartika, And Rice. (2014). Pengarub Faktor Eksternal dan Internal Perusabaan Terbadap Tindakan Perataan Laba. Jurnal Wira Ekonomi Mikroskil, Vol. 4, No. 02.

Sarianti, Putri, And Aan Marinah. (2015). Faktor-Faktor Yang Mempengarubi PP AP Pada Bank Syariah Dan Bank. Konvensional Di Indonesia. Jurnal Bisnis Dan Akuntansi Vol 17, No 1 Juni 2015 Issn 14109875.

Shintya, Nita, And Akhmad Darmaawan. (2014). Analisis Faktor-Faktor YangMemepengarubi Penyisihan Penghapusan Aktiva Produktif (PPAP) Pada Perbankan Syariab Di Indonesia.

Silalahi, Doni. (2014). Analisis Ketahanan Pangan Provinsi Sumatera Utara Dengan Metode Regresi Data Panel. Saintia Matematika. Vol 02 No. 03 237-251.

Sri, Sulistiyanto. (2008). Manajemen Laba: Teori Dan Model Empiris. Jakarta: PT Grasindo, Anggota Ikapi.

Sugiyono. 2019. Metode Penelitian Kuantitatif, KualitatifDan R\&D. Bandung: Alfabeta.

Sujarweni, Wiratna, V. (2015). Metidelogi Penelitian-Bisnis Dan Ekonomi. Yogyakarta: Pustaka Baru Press.

Sulistiyanto, Sri. (2008). Manajemen Laba : Teori Dan Model Empiris. Jakarta: PT Grasindo, Anggota Ikapi.

Syahfandi, Rizky. (2012). Faktor-Faktor Yang Mempengarubi Perataan Laba Penyisiban Pengahapusan Aktiva Produktif. Skripsi. 
Taktak, Boulila, Neila. (2010). Do Islamic Banks Use Loan Loss Provisions To Smooth Their Result?. Journal Of Islamic Accounting And Business Research.

Tan, Anton. (2014). The Real Secret Of Successful Investor And Developer. Jakarta: PT Elex Media Komputindo.

Tripuspitorini, dan Setiawan (2020). Pengarub Faktor Makroekonomi Terhadap Pertumbuban Dana Pibak Ketiga Pada Bank Umum Syariah di Indonesia. Jurnal Riset Akuntansi Dan Keuangan,8 (1), 2020, 121-132.

Tobing, Winson, And Nur Ika Anggrowati. (2009). Perataan Laba Melalui Penyisiban Penghapusan Aktiva Produktif Sektor Perbankan. Jurnal Akuntanbilitas.

Utari, Ratih, Emilia Gustini, And Lukita Tripermata. (2017). Pengaruh Profitabilitas, Financial Leverage, Dan Dividend Payout Ratio Terhadap Perataan Laba Pada Perusabaan Manufaktur Yang Terdaftar BEI. Jurnal Ilmiah Ekonomi Global Masa Kini Volume 8 No.02.

Wijayanti, Rahma, And Vera Diyanti. (2017). Pengarub Volatilitas Laba, Perataan Laba Dan Corporate Governance Terbadap Kualitas Laba Bank Syariah Dan Konvensional. Jurnal Akuntansi Dan Investasi, Vol. 18 No. 1.

Yaya, R., Martawireja, A. E., Dan Abdurahim, (2013). Akuntansi Perbankan Syariah (Teori Dan Praktik Kontemporer Berdasarkan Papsi. Jakarta Selatan: Salemba Empat.

Zoubi, T. Dan Al-Khazali, O. (2007). Empirical Testing of The Loss Provisions Of Banks In The GCC Region. Journal Managerial Finance. Vol. 33, Hal.500 - 511. 